\title{
Ghana's 2012 General Election: Free, Fair, and Flawed?
}

\author{
Kelly Ann Krawczyk
}

Abstract Ghana has held credible, multi-party elections since 1992, with peaceful alternation of power in 2000, 2008, and 2016. Yet despite this strong democratic track record, Ghanaian elections are still regularly marred by allegations of fraud. This case study details the 2012 general election in Ghana, which was contested in the Supreme Court by the main opposition party, the New Patriotic Party (NPP). The case study highlights the use of mechanisms such as election observation and biometric technology in order to increase the credibility of the election and deter fraud. It also outlines the challenges stemming from the use of these tools, including major malfunction of biometric technology, and relocation of fraud to polling places without the presence of observers. An important conclusion we can draw from the Ghanaian experience of 2012 is that

The author wishes to thank Avery Davis-Roberts, Associate Director of the Democracy Program at The Carter Center, for her valuable contributions to this case study.

K. A. Krawczyk $(\bowtie)$

Auburn University, Auburn, AL, USA

e-mail:kak0037@auburn.edu

(C) The Author(s) 2019

M. Brown et al. (eds.), The Future of Election Administration, Elections, Voting, Technology, https://doi.org/10.1007/978-3-030-18541-1_12 
solutions employed to deter electoral fraud, such as the deployment of election observers and the implementation of biometrics, are valuable but insufficient solutions. In some cases, political parties still retain the incentive and ability to manipulate the operation of elections.

Keywords Ghana • Election • 2012 • Biometrics • Election observers

\section{INTRODUCTION}

The country of Ghana, West Africa, enjoys elevated status as the "shining star" of African development (Address to the nation, delivered by Ghanaian President John Dramani Mahama, August 15, 2012). Ghana was the first colony to gain independence from British rule in 1957, and has a history of democratic elections since 1992. While Ghana is considered one of Africa's most stable and highly functioning democracies, accusations of election fraud still regularly tarnish the democratic process (Jockers et al. 2010).

As part of a team of certified international observers from Wayne State University in Detroit, Michigan, I conducted short-term election observation during the 2012 Ghanaian general election. Our team observed eight polling stations in various districts in the Greater Accra Region of Ghana, in and around the country's capital, on December 7, 2012. Although this was a small, nonrepresentative sample of polling stations, it did allow me to observe and experience firsthand the events that unfolded on Election Day.

\section{Ghana's Electoral Environment}

Ghana is a constitutional democracy, and grants universal suffrage at 18 years old. Electoral violence in Ghana is rare, and voter turnout is high. The president is elected by majority vote in a single, nationwide district and serves one four-year term. The country's unicameral parliament is made up of 275 representatives elected by popular vote from single-member constituencies every four years. Elections are held simultaneously for both parliament and the presidency. In 1992, Ghana adopted a new constitution and established the country's Fourth Republic. Since that time, peaceful alternation of the political party holding executive power has occurred three times, in 2000, 2008, and most recently in 2016 . 
Ghana has a competitive, two-party political system. The two major parties, the New Patriotic Party (NPP) and the National Democratic Congress (NDC), are supported by roughly equal numbers of voters, and together these two parties claim more than $95 \%$ of the vote. The NDC and NPP exhibit modest but genuine policy differences, as well as partially distinct social bases of support (Golden et al. 2015).

National politics are highly competitive in Ghana. In the 2008 presidential election, the NDC won with a margin of only 40,000 votes out of an electorate of 14 million (Golden et al. 2015). Partisan competition is not evenly distributed across Ghana's ten regions, however, each party has stronghold areas. The NPP is concentrated in the Ashanti Region, and the NDC is concentrated in Volta. These two regions are commonly thought of as party strongholds, whereas the other eight regions exhibit greater partisan competition (Fridy 2007; Morrison and Hong 2006).

In July 2012, following the death of President John Evans Atta Mills five months before the end of his term, Vice President John Dramani Mahama took office. Competing for the presidency in Ghana's general election on December 7, 2012, were incumbent president John Dramani Mahama of the National Democratic Congress (NDC), his main challenger Nana Akufo-Addo of the New Patriotic Party (NPP), and six other candidates. According to the International Foundation for Election Systems (IFES), Ghana had 14,158,890 registered voters during the 2012 general election. There were 11,246,982 votes cast, and 251,720 invalid votes, resulting in a $78 \%$ voter turnout. The incumbent National Democratic Congress (NDC) candidate, John Dramani Mahama, received $50.7 \%$ of the vote, while the main opposition challenger, Nana AkufoAddo, received $47.7 \%$ of the vote. Because the incumbent president John Mahama obtained a majority, with $50.7 \%$ of votes, there was no runoff election.

\section{Election Observation in GHana}

Ghanaian elections are observed regularly by both domestic and international missions. International missions included the African Union, National Democratic Institute (NDI), and the Electoral Institute for Sustainable Democracy in Africa (EISA). Ghana's Coalition of Domestic Election Observers (CODEO) is perhaps the most well-known and credible domestic observer group, and has been accredited by the Ghanaian Electoral Commission (EC) since 2000. CODEO recruits and trains 
professionals, typically school teachers and college students, to observe the electoral process. CODEO assigns observers to polling stations in their home areas, where observers are likely to be personally known and to enjoy community respect due to the nature of their professions. Each CODEO observer is assigned a single polling station on Election Day. Polling places selected for observation are not identified publicly in advance of the election, meaning that officials and voters at every polling station must realistically anticipate an observer (Golden et al. 2015).

In 2012, CODEO's observers were trained to use short message service (SMS) to report irregularities and disruptions to a national data center. If an incident is serious, CODEO has communication structures in place to alert appropriate legal and security officials. CODEO also releases press statements throughout Election Day and its election headquarters in Accra serves as a hub of public information about the process.

\section{Biometric Election Technology in Ghana During the 2012 General Election}

Despite nearly two decades of election observation intended to deter irregularities, allegations of fraud still occur regularly in Ghanaian elections, especially during the pre-election phase. This may be because this phase of the electoral cycle is observed less frequently. For example, implausibly large numbers of names appeared on the voter rolls leading up to the 2012 election (Oduro 2012).

To help combat such issues, Ghana now employs perhaps the most ambitious application of biometric technology on the African continent, using biometrics for both the voter registration process, and also to authenticate voter identity at the polls ${ }^{1}$ on Election Day (Golden et al. 2015; Piccolino 2016). During the 2012 election cycle, the Electoral Commission of Ghana introduced biometric voter registration in order to verify and de-duplicate data, and reduce multiple registrations. The entire electorate was reregistered using biometric markers (ten fingerprints) during a six-week period in spring 2012. New voter identification cards were issued featuring head shots. This reregistration process identified approximately 8000 double registrations, of which 6000 were judged intentional (Darkwa 2013).

\footnotetext{
${ }^{1}$ Biometric verification machines are used to authenticate voters at the polls. However, actual voting takes place using a paper ballot.
} 
After the biometric registration process was complete, biometric verification machines were delivered to all 26,000 polling stations in the country for use on Election Day. The EC also purchased another 7500 backup machines for use in the event of equipment failure. Because the equipment is battery operated, spare batteries accompanied each machine (Golden et al. 2015). While the combined system of biometric registration and verification was presented as a success, in practice there were serious problems, particularly on Election Day. These issues are discussed in the next section.

\section{Election Issues And Challenges}

The observation undertaken by the Wayne State University team on December 7, 2012, only begins to scratch the surface of the challenges that presented themselves on Election Day. In the Greater Accra Region, we observed polling stations with long lines and crowding in the morning. In three polling stations where we observed, these long lines, coupled with agitated crowds, caused conflict between voters. In another polling station, police were called to settle a dispute over accusations of linecutting. In the remainder of polling places we observed, lines were shorter and voters remained orderly. By the late afternoon, none of the polling stations we visited in Accra had lines. Although the polls reopened the following day in one northern region of Ghana due to failure of biometric voter identification equipment, none of the eight polling stations we visited in Accra reported any difficulties with biometric voter identification equipment (Krawczyk 2013). Yet, it is clear that use of biometric technology, particularly on Election Day, was in fact marred by difficulties.

Biometric technology was utilized on Election Day to verify the identity of voters, by scanning voters' fingerprints at the polls using biometric verification machines. In some cases, however, biometric verification devices failed to identify individuals' thumbprints, and some biometric verification machines failed entirely. The Electoral Commission mandated that no one would be allowed to vote without their identity being verified biometrically. However, approximately $19 \%$ of polling stations experienced a breakdown of the verification machine at some point during the day (Coalition of Domestic Election Observers (CODEO) 2013). Breakdowns appear to be caused by battery overheating and exhaustion, and when battery replacement was attempted, the machines froze up, sometimes for several hours. 
The biometric verification machine breakdowns delayed voting, and by noon on Election Day, Ghana's President, John Dramani Mahama, appealed to the Electoral Commission (EC) to allow individuals with valid voter ID cards to vote at polling stations where biometric verification machines were not functioning. The EC rejected the proposal, instructing their local officials to instead permit voting to continue into a second day where necessary (Golden et al. 2015).

In addition to issues with biometric voter authentication, another issue of credibility arose-over vote-tallying and recording-which ended up distracting attention from the failure of biometric technology. Despite serious technological issues, the candidates, election officials, and donors who supported the introduction of biometric technology failed to question what they considered to be the inherent value of biometric technology. Furthermore, despite its clear limitations, the biometric process received a positive assessment by the general public. According to a survey conducted by CODEO of registered Ghanaian voters, $78 \%$ of respondents agreed biometric registration represented an improvement over the old system, and $87 \%$ of respondents considered it a useful tool for promoting credible and peaceful elections (Piccolino 2016).

The failure of biometric technology did, however, lead to a complaint filed by Nana Akufo-Addo, the presidential candidate of the major opposition party NPP, his running mate Dr. Mahamadu Bawumia, and the Party's Chairman Jake Obetsebi Lamptey. They petitioned the Supreme Court to look into the 2012 elections in light of irregularities. The major charge by Addo and the NPP was related to the use of biometric voting machines: that the EC permitted voting to take place in many polling stations across the country without biometric verification, and these votes were therefore unlawfully included in the declaration of results by the EC in the presidential election. After series of legal battles spanning from April 16 to August 29, 2013, the Supreme Court gave its final judgment, and the NPP's complaint was dismissed.

\section{Empirical Evidence on the IMPACt of Election Observers and Biometrics at the 2012 Polls}

The assumption is that both the presence of election observers, as well as the use of biometric technology, can help reduce electoral fraud and irregularities. Thus, Ghana employed both observers and biometric technology 
during the 2012 election. But did it work? And what is the relationship between election observers and biometric technology? There is empirical evidence from Ghana's 2012 elections that can help explore these questions.

Asunka et al. (2013) provide promising evidence on the ability of observers to deter fraud. Their study, implemented in 2000 polling places ${ }^{2}$ during Ghana's 2012 election, finds that observers significantly reduce overvoting and suspicious turnout at polling stations to which they are deployed, by up to $60 \%$. Yet the very same study also offers less promising results: political parties are able to successfully "relocate" fraud from observed to unobserved stations in their historical strongholds, where they enjoy social penetration and political competition is low. They are not able to do so in politically competitive constituencies.

In 2012, biometric identification machines were used in every polling station in Ghana as a way to reduce fraud. Recall, however, that up to $19 \%$ of these machines failed on voting day. Golden et al. (2015) randomly selected a sample of polling places in four of Ghana's ten regions, in order to study whether election observers impacted biometric machine malfunction. They also examined the effect of observers on fraud in order to analyze the complex relationship between observers, machine malfunction, and electoral fraud.

Golden et al.'s (2015) main finding is that in polling stations with a randomly assigned domestic election observer, biometric identification machines were about $50 \%$ less likely to break down than in polling stations without observers. Second, they found machine breakdown was more prevalent in electorally competitive areas. Third, they also found that three markers of election irregularity-overvoting, registry rigging, and ballot stuffing-were more common in polling stations affected by the breakdown of the biometric identification machines, especially when an election observer was not present. This supports the findings of Asunka et al. (2013) and suggests those seeking to manipulate election results may actually be successfully relocating fraud to polling places without an observer present.

\footnotetext{
${ }^{2}$ The authors of this study partnered with Ghana's Coalition of Domestic Elections Observers (CODEO), and randomly assigned election observers to just over 1000 of Ghana's 26,000 polling places (treatment locations). They also collected data from an additional randomly selected 1000 polling stations to which observers were not deployed (control locations).
} 


\section{Conclusions ANd Lessons LeARned}

Election observation has been an increasingly prevalent tool across the globe, and especially in Africa, in order to curb election irregularities. There has also been a huge increase in the use of biometric technology in elections over the last two decades. In Africa, roughly half of all national elections now use biometric equipment (Cheeseman et al. 2018). While election observation and biometric technology clearly have promise as tools to achieve more credible elections, we must also exercise caution. For example, despite the widespread deployment of election observers, and empirical evidence supporting the contention that observers can help reduce electoral irregularities and fraud, there is evidence that indicates observers may also "displace" fraud to unobserved polling locations. And recent evidence suggests that biometric technology is not infallible: it relies on complex procedures that are liable to break down, and may actually increase suspicion of fraud and encourage complacency toward traditional forms of election oversight (Cheeseman et al. 2018, p. 1398). Due to these limitations, we must carefully consider whether tools such as biometric technology are worth the cost, and whether they can actually achieve intended outcomes.

The case of the 2012 Ghanaian election illustrates these concerns. Biometrics was introduced in an effort to curb electoral irregularities and to produce cleaner elections, yet evidence suggests this may not have happened to the extent which we hoped. The breakdown of biometric machines reduced the ability to authenticate voters, and may have even provided an entrée for those trying to manipulate election outcomes. Electoral management bodies may try to justify the resources required to implement biometrics, but the case of Ghana shows the perils of overpromising what technology can do-it can't change political practice overnight. And when it comes to deploying election observers, the 2012 Ghanaian election provides an argument for greater investment in domestic observer programs, especially if fraud is being relocated to polling places without observers.

An important conclusion we can draw from the Ghanaian experience of 2012, evident in the work of both Asunka et al. (2013) and Golden et al. (2015), is that solutions employed to deter electoral fraud, such as the deployment of election observers and the implementation of biometrics, are valuable but insufficient solutions. In some cases, political parties still retain the incentive and ability to manipulate the operation of elections. 


\section{REFERENCES}

Asunka, Joseph, Sarah Brierley, Miriam Golden, Eric Kramon, and George Ofosu. 2013. Protecting the Polls: the Effect of Observers on Election Frand. Unpublished manuscript. http://cega.berkeley.edu/assets/miscellaneous_files/Asunka_etal_ Protecting_the_Polls.pdf.

Cheeseman, Nic, Gabrielle Lynch, and Justin Willis. 2018. Digital Dilemmas: The Unintended Consequences Of Election Technology. Democratization 25 (8): 1397-1418. https://doi.org/10.1080/13510347.2018.1470165.

Darkwa, Linda. 2013. Ghana's Elections 2012: Some Observations. Social Science Research Council. https://kujenga-amani.ssrc.org/2013/08/15/ghanaselections-2012-some-observations/.

Fridy, Kevin. 2007. The Elephant, Umbrella, and Quarrelling Cocks: Disaggregating Partisanship in Ghana's Fourth Republic. African Affairs 106 (423): 281-305.

Golden, Miriam, Eric Kramon, George Ofosu, and L. Sonnet. 2015. Biometric Identification Machine Failure and Electoral Fraud in a Competitive Democracy. https://www.golden.polisci.ucla.edu/single-post/2015/11/11/ Biometric-Identification-Machine-Failure-and-Electoral-Fraud-in-aCompetitive-Democracy.

Jockers, Heinz, Dirk Kohnert, and Paul Nugent. 2010. The Successful Ghana Election of 2008: A Convenient Myth? The Journal of Modern African Studies 48 (1): 95-115.

Krawczyk, Kelly Ann. 2013. Understanding Local Political Participation in West Africa. Wayne State University Dissertations. Paper 666. Proquest. https:// digitalcommons. wayne.edu $/ \mathrm{cgi} /$ viewcontent .cgi?article $=1665 \&$ context $=0 a_{-}$ dissertations.

Mahama, John Dramani. 2012. Address to the Nation. Speech, August 15.

Morrison, Minion K.C., and Jae Woo Hong. 2006. Ghana's Political Parties: How Ethno-Regional Variations Sustain the National Two-Party System. Journal of Modern African Studies 44 (4): 623-647.

Oduro, Franklin. 2012. Preventing Electoral Violence: Lessons from Ghana. In Voting in Fear, ed. Dorina A. Bekoe. Washington, DC: United States Institute of Peace.

Piccolino, Giulia. 2016. Infrastructural State Capacity For Democratization? Voter Registration and Identification in Cote d'Ivoire and Ghana Compared. Democratization 23 (3): 498-519. 
Open Access This chapter is licensed under the terms of the Creative Commons Attribution 4.0 International License (http://creativecommons.org/licenses/ by $/ 4.0 /)$, which permits use, sharing, adaptation, distribution and reproduction in any medium or format, as long as you give appropriate credit to the original author(s) and the source, provide a link to the Creative Commons licence and indicate if changes were made.

The images or other third party material in this chapter are included in the chapter's Creative Commons licence, unless indicated otherwise in a credit line to the material. If material is not included in the chapter's Creative Commons licence and your intended use is not permitted by statutory regulation or exceeds the permitted use, you will need to obtain permission directly from the copyright holder. 